\title{
Product Policy and Neuromarketing in The Context of Slovak Consumer
}

\author{
Tatiana PETHÖ, Róbert ŠTEFKO and Jaroslava GBUROVÁ
}

Prešov University, Faculty of Management, Prešov, Slovakia

Correspondence should be addressed to: Tatiana PETHÖ; tatiana.petho@unipo.sk

Received date:4 November 2020; Accepted date:26 January 2021; Published date: 5 August 2021

Academic Editor: Hanna Waligórska

Copyright (C) 2021. Tatiana PETHÖ, Róbert ŠTEFKO and Jaroslava GBUROVÁ. Distributed under Creative Commons Attribution 4.0 International CC-BY 4.0

\begin{abstract}
The aim of this paper is to present a theoretical summary of product policy and neuromarketing, as well as to identify differences in the perception of quality and selected forms of promotion, which significantly affect the shopping behavior of Slovak consumers. The research sample consisted of 166 respondents aged from 18 to 60 years ( $53.6 \%$ men). The authors of this paper did not find statistically significant gender differences in the perception of satisfaction with the quality of purchased products. They did not also find statistically significant gender differences of selected forms of product promotion on consumer shopping behavior. Any organization's priority must be to create and find its place in the market and gain the favor of consumers. The result of a good product strategy is customer satisfaction which will be reflected on the organization itself.
\end{abstract}

Keywords: Neuromarketing, Product Policy, Consumer, Slovak Consumer

\section{Introduction}

Marketing is an important tool for achieving business goals. It takes place in market economy conditions, where market demand and supply meet. Many companies, large and small, began to realize the need and importance of marketing, and therefore decided to adapt their business philosophy to marketing, respectively, change their corporate philosophy to marketing. One of the characteristics of the current rapid pace of market development is companies' competitive struggle for customers. There are currently a number of definitions, wordings and versions of the term marketing. One common feature between all these definitions

Cite this Article as: Tatiana PETHÖ, Róbert ŠTEFKO and Jaroslava GBUROVÁ (2021), "Product Policy and Neuromarketing in The Context of Slovak Consumer ", Journal of Marketing Research and Case Studies, Vol. 2021 (2021), Article ID 800872, DOI: 10.5171/2021.800872 
is the customer and the satisfaction of his needs (Rajan, 2005).

Product policy is the core of marketing, because it shapes the offer, an important feature of which is satisfying the needs of the purchasing power. In product policy-making, the basic goal is to make products different from competing products and to reach the target market of consumers who receive them and are willing to pay a higher price for the value offered and for differentiation. Differentiation can be based on physical differences such as features, performance, design, packaging, differences in availability, differences in service, price differences and image differences (Kotler, 2005).

\section{Literature Review}

Several authors deal with the issue of product policy in foreign and domestic professional literature. It is possible to list several important authors whose publications can be found on the domestic as well as foreign markets. Blythe and Zimmerman (2005) define a product as an offer of a company that satisfies the needs of customers. Customers look for benefits when buying a product and they are willing to give up valuable things, including money and time, in exchange for gaining satisfaction. Such satisfaction comes from the basic product and its benefits, the value that the customer actually buys, along with product attributes that include the brand name, design, country of origin, price and packaging as well as support services such as delivery, installation and warranty.

The product or a service is evaluated from two sides, from the point of view of the buyer, whether it is a performance or object that is able to satisfy one wish or one need. The other side is the manufacturer and what it can offer on the market. These are usually services, goods or solvable problems (Štefko et al., 2012). The product in its unaltered form cannot be successfully offered on the market indefinitely due to the constantly changing marketing environment of each company (changes in customer requirements, changing possibilities of the company, the arrival of new competitors, the emergence of new technologies, etc.). Carrying out timely measures not only in the area of product policy (e.g. the need to improve existing products, withdraw products from sale, develop new products, etc.), but also in the area of other tools of the marketing mix allows the company to monitor the product life cycle (Srpová et al., 2010).

Brand is one of the most important aspects of product differentiation for consumers. The most important activities of every company are associated with creating a brand, protecting it, increasing prestige and maintaining the market. Any opinion, term, sign, symbol, design or combination of these elements, the purpose of which is to identify the goods or services of one seller or sales group and to distinguish them from competing goods and services, may be considered a brand (Mulačová et al., 2013).

According to Machkovej (2015), the mark can take various forms and can be represented graphically, verbally or spatially. A mark is a complex symbol that can be expressed by different symbols at different levels of meaning. The brand identifies the manufacturer of the products bringing a number of benefits not only to the consumer but also to the owner of the brand. The value created for the customer is enhanced by the style and design of the product. Design is an important marketing element representing a broader concept than style. Style is more related to the appearance of the product, while design has a much deeper core, which relates to the very basic function of the product. The design of the product reflects the functionality, usability and operation of the product, as well as its appearance. It can give the manufacturer a strong competitive advantage in the target market and is considered a good marketing tool for building a brand, as it helps consumers distinguish similar products. Only a very small number of managers can distinguish between design and value (Kotler et al., 2007). 
Packaging is an important part of the implementation phase of the marketing algorithm and should reflect the ideas of the manufacturer, being a visual and physical proof of the product. The significance of packaging lies in the fact that it conveys a message about the product, the brand and in which category it is included, addressing a typical customer or promoting the benefits of the product (content). The public as well as consumers should be made aware of the product, its uses and benefits. Businesses are aware of the power of good packaging in creating instant knowledge of the brand and business. High-quality and correctly innovated packaging brings a competitive advantage. On the other hand, improperly designed packaging reduces the company's sales and worries consumers. For this reason, it follows that poor communication through packaging leads to bankruptcy (Šalgovičová, 2001).

Through neuromarketing research, information can be obtained on two areas: polarity and activation. Emotional polarity indicates both positive and negative fluctuations from zero, i.e., the extent to which the respondent likes the shot or not. The activation curve indicates the ability of the stimulus to arouse a stronger, less variable emotion, i.e., interest in the product. Thus, the research agency obtains information on the extent to which the spot can influence purchasing decisions. The course of neuro curves must be examined and compared with the results of in-depth interviews and focus mainly on those areas where different data are measured (Tahal et al., 2017).

The main advantage of neuromarketing is the ability to test the impact of communication on an individual's emotions. Unlike other methods, depending on the extent to which and what respondents are willing to reveal about themselves, neuromarketing measures the actual survival of a given activity by individuals at the moment of contact with the stimulus tested. As already mentioned, neuromarketing is used in combination with interview, making it more effective. This is also because it can elucidate many reasons for behavior (Tahal et al., 2017). Among the announced disadvantages of neuromarketing is the fact that it is inappropriate and problematic to apply in the preparatory phase of research, where the emotional response is much lower. Neuromarketing research is very expensive due to the technological equipment needed for this research as well as the prices of the services of neuromarketing agencies. According to Bennett (2011), it is first necessary to determine the price of neuromarketing research in order for a firm to consider whether such research is worthwhile. The costs are usually very high, and therefore, only large companies can afford this research. It is important to compare the results from this research to those from alternative forms of research. The biggest disadvantage of the use of neuromarketing is the weak regulation in terms of ethics. The magnetic resonance method allows one to monitor the activity of the whole brain with no privacy. A lie detector is easier to deceive than modern imaging devices. This means that one has no privacy rights, as one cannot hide any thoughts. Of course, research is always attended by volunteers who are fully aware of the risk associated with the experiment (Fronková, 2016).

\section{Method}

The aim of the research is to identify differences in the perception of quality and selected forms of promotion, which significantly affect the shopping behavior of Slovak consumers.The object of the research was consumers living in the region of eastern Slovakia. The selection of the survey sample was carried out by random selection in the form of a questionnaire. The obtained primary data were subsequently processed in the statistical program Statistica.

To achieve the goal of the research, the following hypotheses were set:

$\mathrm{H}_{1}$ : It is assumed that there are statistically significant differences in the perception of satisfaction with the quality of 
purchased products in the Slovak Republic depending on the gender of the surveyed respondents.

$\mathrm{H}_{2}$ : It is assumed that there are statistically significant differences in the impact of selected forms of product promotion on consumer shopping behavior depending on the gender of the surveyed respondents.

\section{Results}

The research sample consisted of a total of 166 respondents. Based on the processed results, it can be stated respondents aged 18 to 30 years had the largest share in the research, representing 77 participants (46.39\%), followed by 35 respondents $(21.08 \%)$ aged 41 to 50 years, then 29 respondents (17.47\%) 31 to 40 years, and finally 25 respondents $(15.06 \%)$ aged 51 years and above..

As far as completed education is concerned, most respondents (58) have completed tertiary education I. level, representing $34.94 \%$, followed by 52 respondents (31.33\%) have completed secondary education with a high school diploma , 30 respondents (18.07\%) have completed higher education II. and III. degree , 22 respondents $(13.25 \%)$ have completed secondary school without a GCSE, and 4 respondents $(2.41 \%)$ have completed basic education. The research involved 89 interviewed women and 77 men. Women formed a larger group with a share of $53.61 \%$ and men $46.39 \%$.

In the questionnaire, the respondents were asked how they search and buy products on the market. Respondents could choose from 4 closed answers or from the opportunity to express their own opinion. Out of 166 respondents, up to 97 respondents (58.43\%) search for and buy products of a company in the retail chain, $39(23.5 \%)$ in retail, 20 $(12.05 \%)$ over the Internet, $10(6.02 \%)$ from the known, and none of the respondents used the other option.

Price is one of the psychological factors that influence the shopping behavior and shopping decisions of consumers, so the next question aimed at finding out whether the respondents prefer quality over price. Respondents chose from a five-point Likert scale, where 5 means to 'definitely yes', 4 'rather yes', 3 'I don't know', 2 'rather no' and 1 is for 'definitely no'. Up to 63 respondents $(37.95 \%)$ marked the answer earlier not. This means that when buying products, respondents care about their prices rather than quality. Of the 166 respondents, 47 respondents $(28.32 \%)$, on the other hand, prefer quality over price. The answer 'definitely not' was marked by 24 respondents (14.46\%), 'definitely yes' by $18(10.84 \%)$ and 'I do not know the answer' was chosen by 14 respondents $(8.43 \%)$.

The aim of the research hypothesis $\mathrm{H}_{1}$ was to determine whether there are statistically significant differences in the perception of satisfaction with the quality of purchased products in the Slovak Republic depending on the gender of the surveyed respondents. The results are processed in the tables below.

The sample consisted of 89 women and 77 men. Respondents had the opportunity to choose from a five-point Likert scale. The option 'definitely yes' was chosen by 25 men and 18 women, 'rather yes' 37 men and 50 women, 'I do not know' 9 men and 13 women, 'rather not' 5 men and 8 women and the last option 'definitely no' was marked by only 1 man.. 
Table 1: Mean score of quality of services in the context od genderl

Source:(own proceeding)

\begin{tabular}{|c|c|c|c|c|c|c|}
\hline Gender & $\mathbf{n}$ & $\mathbf{5}$ & $\mathbf{4}$ & $\mathbf{3}$ & $\mathbf{2}$ & $\mathbf{1}$ \\
\hline Men & 77 & 19.946 & 40.355 & 10.205 & 6.030 & 0.4634 \\
\hline Women & 89 & & & & & \\
& & 23.054 & 46.645 & 11.795 & 6.969 & 0.536 \\
\hline
\end{tabular}

Table 2: Correlation between gender and quality of services

Source:(own proceeding)

\begin{tabular}{|c|c|}
\hline Pearson's correlation & 4.658 \\
\hline $\mathbf{p}$ & 0.324 \\
\hline
\end{tabular}

The value of the probability captured by Table 2 is $p=0.324$. The level of significance at which the hypothesis is verified, t. j. $\alpha=0.05$ is less than the probability value, so the relationship found is not statistically significant. It can be stated that there are no statistically significant differences in the perception of satisfaction with the quality of purchased products in the Slovak Republic depending on the gender of the surveyed respondents. Therefore, Hypothesis 1 is rejected.

The main task of marketing and marketing communication is to know the customer, reveal his needs and wishes, and communicate with him. Feedback is important for the company itself. The aim of any company is to offer its consumers the greatest possible value. With a suitable marketing strategy, the company builds its competitive position in the market. An organization that wants to succeed in the market must monitor and evaluate competition, adapt its product or service offering to market changes, and be able to reach a large number of users.

Promotion is one of the tools that influence consumers' shopping behavior and shopping decisions. For this reason, the second research hypothesis $\mathrm{H}_{2}$ focused on finding out whether there are statistically significant differences in the impact of selected forms of product promotion on consumer shopping behavior depending on the gender of respondents. Respondents could choose one of the options in the questionnaire, which were selected forms of promotion, namely: 1 Sales promotion, 2 - Advertising, 3 - Personal sales, 4 - Internet, 5 - Social networks, 6 Direct marketing, 7 - New trends in marketing communication. Pearson's Chi-square test of independence was used for verification.

Table 3 captures how men and women answered the question asked. Respondents chose from 7 options offered. Of the 166 respondents, 61 (36.75\%) respondents, 23 men and 38 women, chose the answer 'sales support'. 
Table 3: Mean score of respondent's choice of form of promotion in the context of gender

\begin{tabular}{|c|c|c|c|c|c|c|c|c|}
\hline Gender & $\mathbf{n}$ & $\mathbf{1}$ & $\mathbf{2}$ & $\mathbf{3}$ & $\mathbf{4}$ & $\mathbf{5}$ & $\mathbf{6}$ & $\mathbf{7}$ \\
\hline Men & 77 & 28.295 & 12.060 & 11.132 & 8.349 & 3.246 & 8.349 & 5.566 \\
\hline Women & 89 & & & & & & & \\
& & 32.704 & 13.939 & 12.867 & 9.650 & 3.753 & 9.650 & 6.433 \\
\hline
\end{tabular}

Source:(own proceeding

Table 4: Correlation between gender and choice of form of promotion

\begin{tabular}{|c|c|}
\hline Pearson's correlation & 0.432 \\
\hline $\mathbf{p}$ & 0.612 \\
\hline
\end{tabular}

Source:(own proceeding)

The value of the probability captured by Table 4 is $p=0.612$. The level of significance at which the hypothesis is verified, t. j. $\alpha=0.05$ is less than the probability value, so the relationship found is not statistically significant. It can be concluded that there are no statistically significant differences in the impact of selected forms of product promotion on consumer shopping behavior depending on the gender of the respondents. Hence, Hypothesis 2 is rejected.

\section{Conclusion}

Every day, companies are fighting in the favor of customers. Therefore, in order for a company to function, it must use all possible ways to gain a competitive advantage. The basic element of business is the product, and it is no longer enough to just produce and wait for people to buy the product, but it is necessary to know which products suit the customer. Product strategy is important in terms of long-term, comprehensive and effective operation in the global market. Product policy is part of the marketing mix and its task is to analyze, plan, implement and control product decisions. There is a very diverse competitive environment in the market in which products are lost and indistinguishable. Any organization's priority must be to create and find its place in the market and gain the favor of consumers. The result of a good product strategy is customer satisfaction which will be reflected on the organization itself.

Neuromarketing combines marketing, neurology, psychology or sociology. Marketing is basically anything that helps in grabbing the attention of customers towards a product/service, remembering it and ultimately buying it. Neuromarketing incorporates knowledge from human behavior research into this process; namely buying products/services and why customers perceive them more attractive than others.

\section{Acknowledgement}

This article is one of the partial outputs under the scientific research grant VEGA1/0807/19 "Research on the determinants of trading behavior and marketing effects in the area of neuromarketing and the relation to neurolinguistic programming."

\section{References}

- Bennett, C. (2011). The seven sins of neuromarketing. In [online]. Available on: http://prefrontal. org/blog/2011/ 04/the-seven-sins-of-neuromarketing/

- Blythe, J. and Zimmerman, A. (2005)Business-to-business Marketing Management, London, Thomson Learning.

- Kotler, P. et al. (2007). Moderní marketing, Praha,Grada Publishing.

Tatiana PETHÖ, Róbert ŠTEFKO and Jaroslava GBUROVÁ, Journal of Marketing Research and Case Studies, DOI: 10.5171/2021.800872 
- Kotler, P. (2005). Principles of marketing, New Jersey, Financial Times Prentice Hall.

- Machková, H. (2015). Mezinárodní marketing: strategické trendy a príklady z praxe, Praha,Grada Publishing.

- Mulačová, V. et al. (2011). Obchodnípodnikáníve 21. století,Praha,Grada Publishing.

- Rajan, S. (2005). Marketing Management,India, Tata McGrawHillEducation.
- Srpová, J. et al., (2010). Základypodnikání, Praha,Grada Publishing.

- Štefko, R. et al., (2012). Základymarketing, Prešov, Bookman, s.r.o.

- Tahal, R. et al. (2017). Marketingovývýzkum. Postupy, metody, trendy, Praha,Grada Publishing. 